\title{
The Spiritual Crisis of a Personality as a Sign of the Information Society
}

\section{Духовна криза особистості як ознака інформаційного суспільства}

\section{Halyna Chuiko}

Ph.D. in Philology,

Assistant Professor
Галина Чуйко

кандидат філологічних наук,

доцент

E-mail: halynka2244@ukr.net orcid.org/0000-0002-3424-3348

Researcher ID: D-9477-2D16

Yuryi Fedkovych Chernivtsi

National University,

Chernivtsi, Ukraine

2, Kotsiubynskoho street,

Chernivtsi, 58012

Oleksandr Hudyma

Ph.D. in Psychology,

Assistant Professor
Чернівецький національний університет імені

Юрія Федьковича,

м. Чернівиі, Україна

вул. Коцюбинського, 2 ,

м. Чернівці, 58012

Олександр Гудима

кандидат психологічних наук, доцент

E-mail: hyduma1979@ukr.net orcid.org/0000-0001-8244-7284

Researcher ID: F-8900-2019

Kamianets-Podilskyi National

Ivan Ohiienko University, Kamianets-Podilskyi, Ukraine

61, Ohiienka street,

Kamianets-Podilskyi,

Khmelnytskyi region, 32300
Кал'янець-Подільський національний університет ілені Івана Огієнка, л. Кал'янеиь-Подільський, Україна

вул. Огієнка, 61 , м. Кам'янець-

Подільський, Хмельницька обл., 32300 
Original manuscript received March 05, 2019

Revised manuscript accepted March 22, 2019

The author's contribution: H. Chuiko $-50 \%$, O. Hudyma $-50 \%$. Авторський внесок: Г. Чуйко - 50\%, О. Гудима $-50 \%$.

\section{ABSTRACT}

The article deals with the theoretical analysis of the interpretation of the spiritual crisis phenomenon in psychology and the empirical investigation of the peculiarities of spiritual crisis manifestation in adolescence.

It is stated that it is worth talking about the availability of experiencing spiritual crisis by an individual, when he or she realizes, that moral values are lost, and spirituality gave way to material benefit.

It is noted that the spiritual crisis, which in the technocratic informational era is partly experiencing by all humanity, is experiencing the situation of impossibility of realizing personal spiritual values in relationships with other people and the world, and because of their non-compliance to the societal or universal values, as well as the levelling of their significance for the person itself or the loss of the moral marks.

In the conducted pilot study, according to the purpose of the article, the sample was comprised of students of Yuriy Fedkovych Chernivtsi National University, future psychologists $(n=30)$, average age of the respondents -20 years. The following methods were used: "Diagnostics of a Spiritual Crisis", the test of hardiness of S. Maddi, the scale of tolerance / intolerance to ambiguity of S. Badner, the scale of "Psychological sapience» of $\mathrm{H}$. Conte.

It is revealed that the tendency to experience the spiritual crisis and increase of the intensity of existential vacuum are found by the students with not enough developed hardiness and its components (in particular, involving and challenge), who lack the tolerance in communicating with other people and the psychological wisdom in perceiving their own inner world, in the awareness of feelings and openness to their sensual experience.

It is concluded that those scientists, who consider the experiencing of a spiritual crisis as a positive moment of human life, say about the spiritual development and self-disclosure of a personality as its result, while scientists, who perceive the spiritual crisis as a failure, a break in the life path, analyze its negative consequences and look for ways to overcome them.

Key words: spiritual crisis, spirituality, existential values, meaning of life, spiritual development. 


\section{Вступ}

У наш час соціально-економічної нестабільності країни, хаотичної неврівноваженості світу, поглинутого глобалізаційними процесами та подальшим розвитком і вдосконаленням інформаційних систем і технологій на шляху до впорядкованості на вищому рівні, для багатьох людей не лише поняття духовності, але й суть того, що воно позначає, перетворилося на анахронізм. Ті ж, для кого воно не втратило свого значення, виявляються за впливу такої зовнішньої ситуації, що відповідно відображається на їх внутрішньому самовідчутті, тією чи іншою мірою схильними до переживання духовної кризи. У психології інтерес до проблеми духовності особистості пов'язаний із переходом від розуміння людини винятково як суб'єкта діяльності до усвідомлення самоцінності кожної людини.

Проблеми духовності цікавили ще давніх філософів, тягнучись через століття, проте ще ніколи вони не набували такої актуальності, як у наш час подальшої технологізації й інформатизації соціуму, в якому людина поступово перетворюється на бездушний і бездуховний механізм засіб, інструмент для отримання максимальної економічної вигоди. Про це, як про ринкову орієнтацію характеру сучасної людини, говорив ще Е. Фромм, зазначаючи, що «людина продає свою здатність відповідати бажаному образу, а що вона являє собою насправді, поза цією роллю, не має ніякого значення ... вона зацікавлена не у власній гідності, а в тому, що вона зможе за себе виручити на ринку» (Фромм, 1998: 467).

Різні аспекти проблеми духовності привертали увагу багатьох зарубіжних і вітчизняних учених, які зосередилися, зокрема, на: аналізі сутності й особливостей духовності людини (В. Франкл, 1990; Е. Фромм, 1998; Б. С. Братусь, 1997; В. І. Слободчиков, 2004; В. В. Козлов, 2007; Т. Власевич-Хоркава, 2012; М. В. Савчин, 2013), розгляді суті й особливостей життєвих криз особистості (Е. Ліндеманн, 
1944; Ф. Ю. Василюк, 1984; Б. С. Братусь, 1997; Є. О. Варбан, 2010; Ю. М. Земцов, 2017), вивченні специфіки переживання особистістю та цивілізацією духовної кризи (В. Франкл, 1990; Р. Ассаджиолі, 2002; С. Гроф, 2003; В. І. Слободчиков, 2004; В. В. Козлов, 2007; L. В. Agrimson \& L. В. Taft, 2009; I. М. Щербакова, 2011; Т. Власевич-Хоркава, 2012; Т. М. Дзюба, 2013; J. L. Mcbride, 2014; L. A. Burke \& R. A. Neimeyer, 2016; Ю. М. Земцов, 2017) та ін., проте відсутність згоди у розумінні феномену духовної кризи в психології зумовлює нашу цікавість до зазначеної проблеми.

Мета статті - теоретично проаналізувати тлумачення сутності й особливостей феномену духовної кризи в психології та емпірично дослідити особливості переживання духовної кризи студентами-старшокурсниками.

\section{Завдання статті}

1. Проаналізувати різні підходи до тлумачення духовної кризи в психології у контексті духовності та життєвих криз особистості.

2. Виявити основні проблеми, лакуни та закономірності у розумінні цього феномену.

3. Провести пілотажне емпіричне дослідження особливостей переживання духовної кризи студентами - майбутніми психологами.

\section{Методи та методики дослідження}

У роботі використано систему методів наукового пошуку - теоретичні: теоретико-методологічний аналіз, порівняння, осмислення й узагальнення релевантної до теми дослідження наукової психологічної літератури; емпіричні: 1) методика «Діагностика духовної кризи» (ДДК) Л. В. Шутової й А. В. Ляшук, 2) тест життєстійкості С. Мадді (адаптація Д. О. Леонтьєва, Є. І. Рассказової), 3) шкала толерантності / інтолерантності до невизначеності С. Баднера (адаптована Т. В. Корниловою, М. О. Чумаковою), 
4) шкала «Психологічної розумності» Х. Конте (адаптована М. О. Новиковою, Т. В. Корниловою); математичної статистики - кореляційний аналіз за Ч. Пірсоном.

У методиці «Діагностика духовної кризи» (ДДК) духовна криза розуміється як «переживання втрати буттєвої основи існування» (Восковская (Шутова) \& Ляшук, 2005) людини, що виникає внаслідок переживання «індивідуально емоційно значимої події» та «супроводжується порушенням процесу пошуку сакрального». Методика заснована на принципі суб’єктивного шкалування людиною свого стану, який описують вісім життєвих категорій: страждання, переживання відсутності свободи, страху смерті, самотність, безглуздість, відчуття гріховності, відповідальність, незадоволеність - у трьох часових вимірах; ступінь прояву категорій оцінюється у відсотках. При обробці результатів розраховуються два показники: ймовірності духовної кризи та напруженості екзистенційного вакууму . Крім того, шляхом розрахунку коефіцієнтів для кожного часового виміру визначаються тенденції духовної кризи: прогресивна; регресивна; стагнаційна; пікова та низинна.

Тест життєстійкості - це методика С. Мадді (опитувальник Hardiness Survey) (Леонтьев \& Рассказова, 2006). Жћиттєстійкість - це система переконань людини про себе, світ, відносини з ним, які дають їй змогу витримувати й ефективно долати стресові ситуації. ЖЖиттєстійкість включає три порівняно самостійні компоненти: залученість, контроль, прийняття ризику. Оціночна шкала до зазначеної методики передбачає чотири варіанти відповідей (від 0 до 3 балів) і прямий та зворотний підрахунки результатів. Ступінь прояву життєстійкості загалом та їі компонентів перешкоджає виникненню внутрішнього напруження в стресових ситуаціях за рахунок копінг-стратегій (hardy coping), стійкого подолання стресів і сприйняття їх як менш значущих. Залученість (commitment), згідно С. Мадді, - це схильність людини бути прихильною до людей, peчей і контекстів, утягнутою у життєві події, а не віддаля- 
тися, ізолюватися чи відчужуватися від них, незважаючи на те, наскільки стресові речі стаються. Контроль (control) включає зусилля впливати на результат (наслідки) того, що продовжує відбуватися навколо людини, незважаючи на те, наскільки це складно, замість занурення у пасивність і безсилля. Виклик (challenge) означає бажання постійно вчитися на власному досвіді (як позитивному, так і негативному) замість того, щоб діяти безпечно, уникаючи невпевненості та потенційних загроз. Слід сприймати стрес як нормальну частину життя і можливість учитися, розвиватися, рости у мудрості (Maddi, 2002). С. Мадді підкреслює важливість вираженості всіх трьох компонентів для збереження здоров'я й оптимального рівня працездатності й активності в стресогенних умовах (Maddi, 2002: 174).

Шкала толерантності до невизначеності С. Баднеpa (Budner's Scale of Tolerance - Intolerance of Ambiquity (1962)) діагностує толерантність-інтолерантність до невизначеності. Перероблена та валідизована в 2014 році Т. В. Корниловою, М. А. Чумаковою (Корнилова \& Чумакова, 2014). Згідно С. Баднера, толерантність до невизначеності є особистісною рисою, що визначає ставлення індивіда до неоднозначних, невизначених, тривожних ситуацій, незалежно від знаку цієї невизначеності. Особистість, толерантна до невизначеності, розглядає будь-яку невизначену ситуацію як можливість вибору, розвитку, набуття нового досвіду, не відчуває деструктивної тривоги у невизначених ситуаціях, здатна активно і продуктивно діяти в них. Навпаки, особистість, не толерантна до невизначеності, має високий рівень тривожності в ситуаціях невизначеності чи iii загрози, навіть якщо ця невизначеність позитивно завершиться в майбутньому. Версія Т. В. Корнилової складається із 16 пунктів, які підраховуються в прямих значеннях: від «абсолютно не згодний» - 1 бал до «цілком згодний» -7 балів. «Сирі» бали переводяться в стандартні оцінки, так визначаються 7 рівнів прояву показників. 
Шкала «Психологічної розумності» (англ. Psychological mindedness) - особистісний опитувальник, що вимірює ступінь доступності для людини її внутрішнього світу, досвіду та переживань, те, наскільки вони їй цікаві, у якому ступені вона емоційно залучена до побудови образу «Я» . Розроблена й опублікована в 1990 р. Х. Конте, адаптована М. А. Новіковою і Т. В. Корниловою (Новикова \& Корнилова, 2014). Психологічна розумність виражає зацікавленість людини в рефлексії психічних процесів, їх значення для поведінки, інтенційність стосовно афективної та інтелектуальної сфер. В опитувальнику конструкт психологічної розумності представлений п'ятьма субшкалами: віра в корисність обговорення власних проблем з іншими людьми; суб'єктивна доступність сфери почуттів; бажання обговорювати свої проблеми з оточуючими; інтерес до інтерпретації мотивації власної поведінки та поведінки оточуючих; відкритість новому досвіду (до змін). Шкала містить 45 пунктів, відповіді на які (ступінь згоди респондента з якими) формуються за 4-бальною шкалою Р. Ліккерта; частина пунктів підраховується в зворотних значеннях.

\section{Результати та дискусії}

Поняття «духовність» займає центральне положення в логотерапії В. Франкла, який одним із перших виокремив його як окремий ноетичний (духовний) вимір людини, у якому містяться «цінності та смисли», пов'язавши духовність із життєвим сенсом, а екзистенційну фрустрацію - 3 «внутрішньою порожнечею духовного життя людини» (Франкл, 1990). Він писав: «...я відчуваю, що людство за останні роки до огиди продемонструвало свої інстинкти і потяги. Сьогодні виглядає важливішим нагадати людині, що у неї є Дух, що вона - Духовна істота» (Франкл, 1990).

Аналізу проблеми духовності у психології присвячена монографія М. В. Савчина, який зазначає, що духовний світ і духовність людини визначаються її розумінням і переживанням «істинності та значущості вищих духовних 
цінностей і смислів, спроможністю здійснювати моральні вчинки... що уособлює сутність людського буття» (Савчин, 2013: 23).

У колективній монографії вітчизняних науковців (Психологічні закономірності, 2011: 26) духовність людини тлумачиться як «багатовимірна система, складовими якої є утворення в структурі свідомості та самосвідомості особистості, у яких у формі ціннісних орієнтацій віддзеркалюються її найбільш актуальні морально релевантні потреби, інтереси, погляди, ставлення до навколишньої дійсності, до інших людей, до себе самої, що стали суб'єктивно значущими регуляторами її активності» .

Т. М. Дзюба, підсумовуючи, виокремлює основні контексти, у яких найчастіше вживається поняття духовності: 1) проблема особистісних цінностей і життєвих пріоритетів; 2) духовна творчість, творчість у культурі; 3) трансценденція до чогось вищого, вихід за межі індивідуальної особистості (Дзюба, 2013: 236). Тоді як, на нашу думку, контекстами, 3 якими поняття «духовність» найчастіше пов'язується у науковій психологічній літературі, стають релігійність і моральність людини, з якими духовність не тотожна, проте її тлумачення не може без них обійтися. Коли ж мова заходить про життєві цінності чи творчість, ідеться, швидше всього, про душевність (психічні властивості) людини. До прикладу, Б. С. Братусь духовність сприймає як спільність «векторів» психології та релігії, вважаючи, що психологія може стати «по-християнськи орієнтованою», «християнською», у якій інша людина має не лише загальнолюдську, але й сакральну цінність, будучи «образом і подобою Бога» (Братусь, 1997).

Саме у контексті духовності як важливої характеристики людини особливої актуальної набуває аналіз проблеми духовної кризи особистості.

Про неоднозначність впливу на людину та людство загалом розвитку науки, а особливо техніки, психологи та філософи говорили віддавна. Зокрема, С. Гроф зазначає, 
що світогляд, домінуючий сьогодні в культурі, несумісний із поняттям про духовність, де «безпосередні переживання духовних реальностей інтерпретуються як психотичні» (Гроф, 2003).

Т. Власевич-Хоркава додає: «...особливістю сучасної техногенної цивілізації, де пріоритетними є матеріальні цінності, є занепад духовності...», що проявляється у переживанні та поширенні духовної кризи - «це духовна криза людства, безмежне провалля, у яке ми щодня поринаємо, не помічаючи цього... Цивілізація, позбавлена духовної суті, породжує небезпеку самознищення всього живого» (Власевич-Хоркава, 2012). Тобто, науковець схильна ототожнювати індивідуальну та соціальну духовну кризу.

В. В. Козлов також вважає, що духовну кризу може переживати не лише особистість, вона може «охоплювати малі та великі соціальні групи, хоча за походженням, змістом, етапами і векторами розвитку особистісна духовна криза не відрізняється від соціально-психологічної кризи» (Козлов, 2007: 267).

Цікаво, що й у словнику духовна криза тлумачиться як особистісна чи суспільна, ніж індивідуальна: «криза суспільних ідеалів і цінностей, що складають моральне ядро культури i додають культурній системі якість органічної цілісності, автентичності...» (Энциклопедический словарь, 2013).

С. Гроф першим увів поняття духовної кризи як «стану, який, з одного боку, володіє всіма якостями психопатологічного порушення, а з іншого - має духовний вимір і потенційно здатний вивести індивіда на вищий рівень існування» (Козлов, 2007: 277). Він також констатував втрату духовності “у колективному масштабі», яка «може виявитися істотним чинником існуючої небезпеки глобальної кризи, що загрожує виживанню людства і всього життя на цій планеті» (Гроф, 2003).

Т. Власевич-Хоркава (Власевич-Хоркава, 2012) вважає передумовою сучасної духовної кризи у культурі «розрив» 
між технократичним і гуманітарним типами мислення, i ми можемо з нею у цьому погодитися. Проте додамо: якщо гуманістично спрямована людина орієнтується перш за все на смисложиттєві та загальнолюдські моральні иінності, то технічно зорієнтована - ставить иілі й намагається усіма способами досягти їх, бачачи саме в цьому сенс і не задумуючись ні про мораль чи совість, ні про засоби.

На наш погляд, духовна криза певною мірою торкнулася якщо не всього, то значної частини людства, яке, живучи в інформаційному суспільстві, позбулося через незначущість і навіть подекуди непотрібність (нефункціональність) духовних цінностей і орієнтирів, принаймні, більшості з них (іноді - нівелюється цінність навіть людського життя (зокрема, під час війни)), більш того - навіть не помічаючи цього. Зрештою, самі характеристики інформаційного суспільства не містять позиції, у якій би відображалася турбота про людину в технократичному соціумі та про її психічний і духовний стан. Необхідно зазначити, що у психології до вивчення людини - представника такого соціуму - та їі долі звертаються частіше гуманістично й екзистенційно зорієнтовані психологи, серед яких одне з найважливіших місць належить Е. Фромму (Фромм, 1998), який понад півстоліття тому виявив, що з розвитком технологічного суспільства чи не домінуючим у ньому стає ринковий тип соціального характеру людини, яка себе й інших людей оцінює як товар, за вартістю продажу. Проте, на нашу думку, схильність до переживання духовної кризи в умовах такого соціуму мають саме ті, у кого, за Е. Фроммом, переважає плодотворна орієнтація характеру, - саме вони зберігають здатність відчувати справжні емоції, переживати втрату чи нівелювання духовних цінностей у їх житті, переживаючи це як духовну кризу (Фромм, 1998). Однак про наявність переживання духовної кризи окремою людиною, на нашу думку, варто говорити, коли вона усвідомлює втрату моральних цінностей, що духовність поступилася місцем матеріальній вигоді чи 
пошуку вражень, і глибоко переживає цю ситуацію, розуміючи необхідність відновлення аксіологічної сутності загальнолюдської моральності та духовності у власному житті й сподіваючись на це.

Виходячи з позиції, що криза - це ситуація неможливості реалізувати потреби власного життя людини (Василюк, 1984), це саме «емоційна реакція людини на загрозливу ситуацію, а не сама ситуація» (Варбан, 2010: 123), то духовна криза - це переживання людиною ситуації духовної самотності, неможливості реалізувати у світі, стосунках 3 іншими людьми свої духовні цінності через їх невідповідність тому, що вважається важливим у цьому соціумі, що в результаті зумовлює конформне нівелювання моральних цінностей людини, з одного боку, та їх трансформацію у прийняті соціумом, до якого належить людина, - 3 іншого; це криза невизначеності людини, що є (що вважати) добром, а що - злом.

Зарубіжні вчені першим дослідженням з теорії криз вважають роботу Е. Ліндеманна, що стосувалася симптоматики переживання гострого горя та терапії осіб, складні життєві обставини яких зумовили це переживання (Lindemann, 1944). Вплив цієї наукової праці на подальші дослідження криз у психології настільки сильний, що більшість сучасних зарубіжних науковців, навіть розуміючи духовну кризу як комплексне явище: «... це щось значно більше i глибше, ніж психічний, фізичний чи соціальний крах, хоча ці складові теж присутні» у ній (Mcbride, 2014), - вважають їі наслідком душевної травми, зокрема, втрати близької (коханої) людини (Mcbride, 2014; Burke \& Neimeyer, 2016; Agrimson \& Taft, 2009), та наголошують на її релігійному елементі (Burke \& Neimeyer, 2016). Тому доводиться констатувати, що поняття духовного (стосовно кризи) тут використовується у значенні душевного (психічного), через що закономірною виглядає заміна поняття «духовна криза» на «духовний стрес» (Burke \& Neimeyer, 2016). 
Зазначимо, що у науці досі відсутне хоча б відносно одностайне тлумачення духовної кризи, та досить часто їі розуміють як кризу цінностей і життєвого сенсу людини (власне, як смисложиттєву кризу), тим більше, що її подальші характеристики зазвичай запозичуються в екзистенціалістів; при цьому вчені зазначають, що смисложиттєва криза - лише різновид духовної. На нашу думку, варто було б їх розрізнити, розуміючи, що духовна криза - більш загальне поняття, ніж смисложиттєва криза.

Зважаючи на причини духовної кризи, виокремлені В. В. Козловим (деформація структури Его, неможливість реалізувати основні тенденції особистості та криза вітальності (невідповідність життєвих сил і енергії людини ситуаціï)) (Козлов, 2007: 16-17), будь-яка життєва криза може вважатися духовною, з чим ми не готові погодитися, вважаючи духовну кризу особливим видом життєвої кризи, пов'язаної з проблемою духовності людини, втратою нею духовних (світоглядних, а не обов'язково релігійних) і моральних орієнтирів. Духовна криза вирішується у стосунках і ставленнях людини до світу. Духовність - це те, що робить людину людиною (людяність), що відрізняє її від решти матеріального світу.

Варто також зазначити, що поняття "духовна криза», очевидно, може мати як широке, так і вузьке значення. У широкому розумінні смисложиттєва і будь-яка життєва (що відбувається у житті людини) кризи - водночас духовні (й душевні), відмінні від матеріальних за походженням. Однак, у вузькому тлумаченні власне духовної кризи - це криза не лише духу, але й духовності та моральності людини, що веде до втрати саме моральних орієнтирів життя особистості.

В. В. Козловим представлений власний (однак, досить залежний від поглядів Р. Ассаджиолі) погляд на духовну кризу, яку він визначає як «особливий етап у розвитку особистості, коли ініціюється процес об'єднання внутрішніх підсистем ... «Я» у єдиний цілісний простір, настає час пе- 
реоцінки всіх цінностей... особистість починає переосмислювати своє місце в житті й основні екзистенції» (Козлов, 2007).

I. М. Щербакова також зазначає, що «духовна криза є точкою біфуркації, тимчасовим станом втрати духовної рівноваги, спричиненим порушенням балансу в системі ціннісних орієнтацій людини, i характеризується трансформаційними змінами на рівні потребово-ціннісного компонента духовності» (Щербакова, 2011: 15).

Цікавість викликає можлива причина «порушення балансу», яка, на наш погляд, може бути двоякою: «духовну рівновагу» людина може втратити як виявивши, що їі духовні цінності не відповідають прийнятим у соціумі (соціальній групі, до якої належить людина), так і через те, що змінилася вона сама, «виросла» 3 колишніх цінностей, реалізувавши їх, чи «переросла». Додамо: існують загальнолюдські моральні цінності, що не потребують трансформації; з іншого боку, духовні цінності нижчого порядку навряд чи спричинять глибоку духовну кризу особистості (хіба що вони настільки значущі для людини, що «вбудовані» у структуру особистості).

Криза духовності, на наш погляд, проявляється, зокрема, в тому, що сучасна людина перестала турбуватися про власну душу, ㄲï цінність і відповідність моральності, замінивши це прагненням усе більшої вигоди: панування людини над природою не пройшло безслідно для обох, i чим далі, тим очевиднішим стає те, що його наслідки ще довго відгукуватимуться як нашим сучасникам, так і потомкам, як «помста природи» взагалі та природи людини зокрема за зроблене з ними самою людиною.

Із погляду Р. Ассаджиолі, наслідком переживання людиною духовної кризи є духовний розвиток - «різка зміна "нормальних" елементів особистості, пробудження досі прихованих здібностей, піднесення свідомості до нових сфер і функціонування особистості в їі новому внутрішньому вимірі» (Ассаджиоли, 2002: 57). 
Схоже бачить духовний розвиток і В. І. Слободчиков, йому духовний розвиток людини представляється як «індивідуалізація буття людини, трансцендентування всередину себе, у глибини суб'єктивності, людської самості й висвічування їі» - це умова «зустрічі з безкінечністю духовного царства, з безкінечністю Божественної Реальності, у якій утворюється дійсно повне, вільне «буття-у-самогосебе» (Слободчиков, 2004).

У науковій літературі зустрічається тлумачення кризи як небезпеки та можливості. Проте, у процесі кризи «можливість» $\mathrm{i}$ «небезпека» розподілені нерівномірно: у їі гострому періоді домінує сприйняття їі як небезпеки, тоді як розуміння можливостей, які передбачає життєва криза, може з'явитися наприкінці її переживання, коли відомі їі результати (Чуйко \& Комісарик, 2019). Крім того, можливим, на нашу думку, є випадок, коли небезпека i можливість не поєднуються у процесі переживання кризи, а стосуються різних видів кризи. Так, духовну кризу деякі вчені тлумачать як можливість (просвітлення, духовне пробудження з відповідними позитивними наслідками), інші - бачать у ній переважно небезпеку (результати такої духовної кризи можуть виявитися не прогнозованими і зовсім не позитивними для людини). Зокрема, на духовній кризі як можливості саморозвитку людини зосереджує увагу психосинтез Р. Ассаджиолі (Дмитренко \& Чуйко, 2002). Унаслідок такої кризи «життя наповнюється сенсом і метою, його повсякденні завдання оживляє і підносить зростаюче в ньому усвідомлення їх місця в загальному порядку речей» (Гроф, 2003).

Проте, навіть зважаючи на те, що переживання духовної кризи здатне сприяти подальшому духовному розвитку особистості, більшість психологів убачають у духовних кризах небезпеку для людини, її здоров'я.

У проведеному нами, відповідно до мети статті, пілотажному дослідженні вибірку склали студенти-третьокурсники Чернівецького національного університету імені 
Юрія Федьковича - майбутні психологи $(\mathrm{n}=30)$, середній вік досліджуваних - 20 років. Дослідження проводилося в груповій формі, письмово; тривалість дослідження від 45 до 60 хв. Використовувався комплекс методик, що складався 3: методики «Діагностика духовної кризи» Л. В. Шутової й А. В. Ляшук; тесту життєстійкості С. Мадді (адаптація Д. О. Леонтьєва, Є. І. Рассказової), шкали толерантності / інтолерантності до невизначеності С. Баднера (адаптована Т. В. Корниловою, М. О. Чумаковою) та шкали «Психологічної розумності» X. Конте (адаптована М. О. Новиковою, Т. В. Корниловою). Обробку результатів здійснювали шляхом підрахунку відсотків і проведення кореляційного аналізу за Ч. Пірсоном.

За результатами емпіричного дослідження виявлено:

- усі опитані тією чи іншою мірою переживають духовну кризу (як стан втрати буттєвої основи існування), причому за прогресивним типом - 23,33\%, за регресивним - 60\% (найбільше у вибірці), стагнаційну і низинну по 3,33\% респондентів, пікова криза - у 30\% опитаних; низький рівень відчуття духовної кризи виявлено лише у 10\%, тоді як середній - у 90\% досліджуваних; напруженість переживання екзистенційного вакууму відсутня також у $10 \%$ студентів (причому $6,67 \%$ з них не відчувають і духовних проблем), у решти $90 \%$ опитаних - вона на середньому рівні;

- у минулому, за оцінкою опитаних, лише 13,33\% не переживали духовну кризу; в теперішньому часі їі відчуття відсутнє лише в $3,33 \%$ студентів, проте з'являється стільки ж, у кого рівень її переживання високий; у майбутньому, за прогнозами досліджуваних, 6,67\% переживатимуть високий рівень духовної кризи, тоді як 16,67\% - вірять, що духовної кризи у них не буде; з усієї вибірки лише в 3,33\% опитаних переживання духовної кризи практично відсутнє за всіма показниками методики; загалом, респондентів найбільше тривожить теперішня ситуація, що зу- 
мовлює кризові переживання, тоді як майбутнє сприймається ними оптимістичніше;

- у переважної більшості опитаних виявлено середній рівень як загального показника життєстійкості, так і його складових, крім того, життєстійкість на високому рівні проявляється лише у $6,67 \%$, тоді як на низькому - у $23,33 \%$ студентів; гірше від решти у вибірці розвинута залученість (у $30 \%$ низький і лише у $3,33 \%$ - високий рівні прояву цього показника), тоді як найсильніше серед складових життєстійкості - схильність до ризику (в 43,33\% опитаних - високий рівень показника);

- показник нетолерантності до невизначеності у переважної більшості студентів проявляється на середньому та дещо вищому рівнях (за винятком $3,33 \%$ нижчого рівня показника), толерантність же - на низькому і нижче середнього рівнях; порівняння показників виявляє, що у $63,33 \%$ опитаних переважає толерантність, у 33,33\% інших - інтолерантність до невизначеності (в 3,33\% респондентів показники рівні); тобто, опитані часто нетерпимі до невизначеності, намагаючись зберегти попередній статускво;

- серед параметрів психологічної розумності в опитаних переважає зацікавленість своїми переживаннями (середня - 15,55 бала, що відповідає 74,05\% максимального значення показника), дещо менші прояви розуміння корисності обговорення своїх переживань (середня - 68,22\% ) та відкритості власному досвіду $(66,4 \%)$, тоді як решта показників - доступності переживань і бажання обговорювати пережите - у вибірці виявляються менше, причому якщо за останнім показником серед опитаних частіше, ніж за іншими, проявляється низький рівень (у $36,67 \%$ ), то користь від обговорення своїх переживань - у 43,33\% опитаних - на високому рівні; загалом, в усій вибірці проявляється середній рівень психологічної розумності;

- проведений нами кореляційний аналіз результатів дослідження за методикою Ч. Пірсона виявив існування 
кореляційного зв’язку між показниками методики «Діагностика духовної кризи» й іншими методиками, використаними в роботі (при $\mathrm{p} \leq 0,05)$; отже:

- до переживання духовної кризи схильні студенти зі слабко розвинутою життєстійкістю загалом $(\mathrm{r}=-0,51)$ та недостатньою сформованістю її складових: залученості до потоку життя $(\mathrm{r}=-0,54)$ і схильності до ризику $(\mathrm{r}=-0,56)$; які не проявляють психологічну розумність в аспекті відкритості до досвіду власних переживань $(\mathrm{r}=-0,43)$;

- відносну напруженість екзистенційного вакууму відчувають опитані, недостатньо залучені до процесу життя $(\mathrm{r}=-0,38)$ та слабко відкриті до сприйняття досвіду власних переживань $(\mathrm{r}=-0,49)$;

- у часовому варіанті переживання духовної кризи спостерігаємо: минуле пов'язане з нетолерантністю до інших людей у спілкуванні та стосунках із ними $(\mathrm{r}=-0,41)$; теперішне - з недостатньою залученістю до плину життя $(\mathrm{r}=-0,54)$ і небажанням ризикувати $(\mathrm{r}=-0,58)$, обираючи подальший особистісний ріст і розвиток; із психологічною розумністю ( $\mathrm{r}=-0,38)$, що проявляється переважно у відсутності відкритості досвіду своїх переживань $(\mathrm{r}=-0,37)$ i бажанні їх обговорювати (демонструвати іншим) $(\mathrm{r}=-0,39)$; бачення майбутнього - з проблемами залученості $(\mathrm{r}=-0,45)$ і схильності до ризику $(\mathrm{r}=-0,44)$; психологічною розумністю як бажанням обговорювати з іншими власні переживання $(\mathrm{r}=-0,37)$.

\section{Висновки}

Духовна криза - це переживання людиною ситуації неможливості реалізувати у стосунках з іншими людыми та у світі власні духовні (моральні) цінності як через невідповідність їх цінностям соціуму, так і через нівелювання їх значущості для самої людини чи втрату нею моральних орієнтирів. Духовна криза, яку в технократичну інформаційну епоху почасти переживає все людство, насправді стосується кожної людини по-своєму, і саме вона повинна 
вирішити її для себе, знайти власний шлях виходу з неї, віднайшовши свої моральні орієнтири та духовні цінності.

Духовну кризу як переважно небезпеку, в негативному ключі, бачать ті науковці, хто схильний не розділяти власне духовну та смисложиттєву кризи, вважаючи основним (ядром духовної кризи) втрату людиною сенсу життя. Науковці, які вважають переживання духовної кризи позитивним моментом життя людини, говорять про духовний розвиток і саморозкриття особистості як її результат, тоді як учені, хто сприймає духовну кризу як крах, злам на життєвому шляху людини, аналізують її негативні наслідки та шукають способи їх подолання.

Схильність до переживання духовної кризи та збільшення напруженості екзистенційного вакууму виявляються студентами з недостатньо розвинутими життєстійкістю та їі компонентами (зокрема, залученістю та прийняттям ризику), яким бракує толерантності у спілкуванні з іншими людьми та психологічної розумності у сприйнятті власного внутрішнього світу, в усвідомленні переживань і відкритості до свого відчуттєвого досвіду.

Перспективу подальшого дослідження вбачаємо у теоретичному аналізі феномену духовності та його розуміння в психології.

\section{Література}

Ассаджиоли Р. Психосинтез. Принципы и техники. Москва : ЭКСМОПресс, 2002. $416 \mathrm{c}$.

Братусь Б. С. К проблеме человека в психологии. Вопросы психологии. 1997. № 5. URL: http://psylib.org.ua/books/_bratu01.htm.

Варбан Є. О. Життєва криза: поняття, концепції та прояви. Проблели сучасної психології: Збірник наукових праць КПНУ імені Івана Огієнка, Інституту психологї ім. Г. С. Костюка АПН України. 2010. Вип. 8. С. 120-133.

Василюк Ф. Е. Психология переживания (анализ преодоления критических ситуаций). Москва : Изд-во Моск. ун-та, 1984. 200 с.

Власевич-Хоркава Т. Особливості сучасної техногенної цивілізації та вияви кризи духовності людини. Вісник Львівського університету. Серія Філософські науки. 2012. Вип. 15. С. 154-161. 
Восковская (Шутова) Л. В., Ляшук А. В. Духовный кризис: проблемы определения и диагностики. Психологическая диагностика. 2005. № 1. С. 51-71.

Гроф К., Гроф С. Духовный кризис. Когда преобразование личности становится кризисом. Москва : ACT, 2003. 384 с. URL: http:// bookap.info/trans/grof_duhovnyy_krizis_kogda_preobrazovanie_ lichnosti_stanovitsya_krizisom/.

Дзюба Т. М. Духовна криза в життєвому просторі особистості. Вісник Одеського національного університету іл. I. І. Мечникова. Серія: Психологія. 2013. Т. 18. Вип. 27 (1). С. 235-241.

Дмитренко А. К., Чуйко Г. В. Основи гуманістичної психології: навч.метод. посіб. Чернівці : Прут, 2002. 268 с.

Духовный кризис. Энциклопедический словарь по психологии и педагогике. URL: https://psychology_pedagogy.academic.ru/6099/ ДУХОВНЫЙ кРИЗИС.

Козлов В. В. Интегративная психология: пути духовного поиска, или Освящение повседневности. Москва : Психотерапия, 2007. 528 с.

Корнилова Т. В., Чумакова М. А. Шкалы толерантности и интолерантности к неопределенности в модификации опросника С. Баднера. Эксперилентальная психология. 2014. № 1. С. 92-110.

Леонтьев Д. А., Рассказова Е. И. Тест жизнестойкости. Методическое руководство по новой методике психологической диагностики личности с широкой областью применения. Москва : Смысл, 2006. $63 \mathrm{c}$.

Новикова М. А., Корнилова Т. М. «Психологическая разумность» в структуре интеллектуально-личностного потенциала (адаптация опросника). Психологический журнал. 2014. № 1, т. 35. С. 95-110.

Психологічні закономірності розвитку духовності особистості: монографія / М. Й. Боришевський, О. В. Шевченко, Н. Д. Володарська та ін.; за заг. ред. М. Й. Боришевського. Київ : Педагогічна думка, 2011. $200 \mathrm{c.}$

Савчин М. В. Духовна парадигма психології: монографія. Київ : Академвидав, 2013. 252 с.

Слободчиков В. И. Индивидуальность как способ духовного бытия человека. Новые иенности в образовании. 2004. № 2. С. 3-13.

Франкл В. Человек в поисках смысла: сборник / Общ. ред. Л. Я. Гозмана и Д. А. Леонтьева; вст. ст. Д. А. Леонтьева. Москва : Прогресс, 1990. $368 \mathrm{c.}$

Фромм Э. Бегство от свободы. Человек для себя. Минск : ООО «Попурри», 1998. $672 \mathrm{c}$.

Чуйко Г. В., Комісарик М. І. Проблема життєвих криз особистості у психології. Психологічний часопис: Збірник наукових праць. 2019. № 1 (21). C. 41-56. DOI https://doi.org/10.31108/1.2019.1.21.3. 
Щербакова I. М. Філософія подолання духовної кризи особистості засобами освіти в період глобалізації та інформаційної революції: автореф. дис. ... канд. філос. наук: 09.00.10 / Нац. пед. ун-т ім. М. П. Драгоманова. Київ, 2011. 20 с.

Agrimson, L. B., \& Taft, L. B. (2009). Spiritual crisis: a concept analysis. The Journal of Advanced Nursing (JAN), 65 (2), 454-461. DOI 10.1111/j.1365-2648.2008.04869.x.

Burke, L. A., \& Neimeyer, R. A. (2016). Inventory of Complicated Spiritual Grief: Assessing Spiritual Crisis Following Loss. Religions, 7, 67. DOI 10.3390/rel7060067.

Lindemann, E. (1944). Symptomatology and management of acute grief. American Journal of Psychiatry, 101 (2), 141-148. DOI 10.1176/ajp. 101.2.141.

Maddi, S. R. (2002). The story of hardiness: twenty years of theorizing, research and practice. Consulting psychology journal: practice and research, 54 (3), 173-185.

Mcbride, J. L. (2014). Spiritual Crisis Surviving Trauma to the Soul. London \& New York : Routledge / Taylor \& Francis Group.

\section{References}

Assadzhioli, R. (2002). Psihosintez. Principy i tehniki [Psychosynthesis. Principles and techniques]. Moskva : JEKSMO-Press [in Russian].

Bratus', B. S. (1997). K probleme cheloveka v psihologii [To the problem of man in psychology]. Voprosy psihologii - Psychology issues, 5. Retrieved from http://psylib.org.ua/books/_bratu01.htm [in Russian].

Varban, Ye. O. (2010). Zhyttieva kryza: poniattia, kontseptsii ta proiavy [Life crisis: the notion, the concepts and manifestations]. Problemy suchasnoi psykholohii-Problems of modern psychology: Collection of research papers of Kamianets-Podilskyi National Ivan Ohiienko University, 8, 120-133 [in Ukrainian].

Vasiljuk, F. E. (1984). Psihologija perezhivanija (analiz preodolenija kriticheskih situacij) [Psychology of experiencing (analysis of overcoming critical situations )]. Moskva : Izd-vo Mosk. un-ta [in Russian].

Vlasevych-Horkava, T. (2012). Osoblyvosti suchasnoi tekhnohennoi tsyvilizatsii ta vyiavy kryzy dukhovnosti liudyny [Features of modern technogenic civilization and manifestations of the crisis of human spirituality]. Visnyk Lvivskoho universytetu. Seriia Filosofski nauky - Newsletter of Lviv University. Series Philosophical science, 15, 154-161 [in Ukrainian].

Voskovskaja (Shutova), L. V., \& Ljashuk, A. V. (2005). Duhovnyj krizis: problemy opredelenija i diagnostiki [Spiritual crisis: problems of definition and diagnostics]. Psihologicheskaja diagnostika-Psychological diagnosis, 1, 51-71 [in Russian]. 
Grof, K., \& Grof, S. (2003). Duhovnyj krizis. Kogda preobrazovanie lichnosti stanovitsja krizisom [Spiritual crisis. When transformation of personality becomes a crisis]. Moskva : AST. Retrieved from http:// bookap.info/trans/grof_duhovnyy_krizis_kogda_preobrazovanie_ lichnosti_stanovitsya_krizisom/[in Russian].

Dziuba, T. M. (2013). Dukhovna kryza v zhyttievomu prostori osobystosti [Spiritual crisis in the person's living space]. Visnyk Odeskoho natsionalnoho universytetu im. I. I. Mechnykova. Seriia PsykholohiiaScientific Journal of Odesa I. I. Mechnikov National University. Series: Psychology, 27 (1), Vol. 18, 235-241 [in Ukrainian].

Dmytrenko, A. K., \& Chuiko, H. V. (2002). Osnovy humanistychnoi psykholohii [Basics of humanistic psychology]. Chernivtsi : Prut [in Ukrainian].

Duhovnyj krizis (2013). Jenciklopedicheskij slovar' po psihologii i pedagogike - Encyclopedic Dictionary on Psychology and Pedagogy. Retrieved from https://psychology_pedagogy.academic.ru/6099/ DUHOVNYJ_KRIZIS [in Russian].

Kozlov, V. V. (2007). Integrativnaja psihologija: puti duhovnogo poiska, ili osvjashchenie povsednevnosti [Integrative psychology: ways of spiritual search, or sanctification of everyday life]. Moskva : Psihoterapija [in Russian].

Kornilova, T. V., \& Chumakova, M. A. (2014). Shkaly tolerantnosti i intolerantnosti k neopredeljonnosti v modifikacii oprosnika S. Badnera [Scales of tolerance and intolerance to ambiquity in the modification of the S. Badner's questionnaire]. Jeksperimental'naja psihologija Experimental Psychology, 1, 92-110 [in Russian].

Leont'ev, D. A., \& Rasskazova, E. I. (2006). Test zhiznestojkosti. Metodicheskoe rukovodstvo po novoj metodike psihologicheskoj diagnostiki lichnosti s shirokoj oblast'ju primenenija [Hardiness Test. Methodological guidance on the new method of psychological diagnostics of personality with wide scope of application]. Moskva : Smysl [in Russian].

Novikova, M. A., \& Kornilova, T. M. (2014). «Psihologicheskaja razumnost'» v strukture intellektual'no-lichnostnogo potenciala (adaptacija oprosnika) [ "Psychological rationality» in the structure of intellectual and personal potential (adaptation of the questionnaire)]. Psihologicheskij zhurnal - Psychological Journal, 1, Vol. 35, 95-110 [in Russian].

Boryshevs'kyi, M. Yi., Shevchenko, O. V., \& Volodarska, N. D. et. al. (2011). Psykholohichni zakonomirnosti rozvytku dukhovnosti osobystosti [Psychological regularities of development of spirituality of the personality]. M. Boryshevskyi (Ed.). Kyiv : Pedahohichna dumka [in Ukrainian]. 
Savchyn, M. V. (2013). Dukhovna paradyhma psykholohii [Spiritual paradigm of psychology]. Kyiv : Akademvydav [in Ukrainian].

Slobodchikov, V. I. (2004). Individual'nost' kak sposob duhovnogo bytija cheloveka [Individuality as a way of a human spiritual being]. Novye cennosti $v$ obrazovanii - New values in education, 2, 3-13 [in Russian].

Frankl, V. (1990). Chelovek $v$ poiskah smysla [Man in search of meaning]. L. Ja. Gozman, D. A. Leont'ev (Eds.). Moskva : Progress [in Russian].

Fromm, Je. (1998). Begstvo ot svobody. Chelovek dlja sebja [Escape from freedom. Man for himself]. Minsk : OOO «Popurri» [in Russian].

Chuiko, H. V., \& Komisaryk, M. I. (2019). Problema zhyttievykh kryz osobystosti u psykholohii [The problem of life crises of personality in psychology]. Psykholohichnyi chasopys - Psychological journal, 1 (21), 41-56. DOI https://doi.org/10.31108/1.2019.1.21.3 [in Ukrainian].

Shcherbakova, I. M. (2011). Filosofiia podolannia dukhovnoi kryzy osobystosti zasobamy osvity $\mathrm{v}$ period hlobalizatsii ta informatsiinoi revoliutsii [Philosophy of overcoming the spiritual crisis of personality by means of education in the period of globalization and information revolution]. Extended abstract of candidate's thesis. Kyiv : Nats. ped. un-t im. M. P. Drahomanova [in Ukrainian].

Agrimson, L. B., \& Taft, L. B. (2009). Spiritual crisis: a concept analysis. The Journal of Advanced Nursing (JAN ), 65 (2), 454-461. DOI 10.1111/j.1365-2648.2008.04869.x.

Burke, L. A., \& Neimeyer, R. A. (2016). Inventory of Complicated Spiritual Grief: Assessing Spiritual Crisis Following Loss. Religions, 7, 67. DOI 10.3390/rel7060067.

Lindemann, E. (1944). Symptomatology and management of acute grief. American Journal of Psychiatry, 101 (2), 141-148. DOI 10.1176/ajp. 101.2.141.

Maddi, S. R. (2002). The story of hardiness: twenty years of theorizing, research and practice. Consulting psychology journal: practice and research, 54 (3), 173-185.

Mcbride, J. L. (2014). Spiritual Crisis Surviving Trauma to the Soul. London \& New York : Routledge / Taylor \& Francis Group.

\section{Чуйко Галина, Гудима Олександр. Духовна криза особистості як ознака інформаційного суспільства}

\section{АНОТАЦІЯ}

Стаття пов'язана з теоретичним аналізом інтерпретації феномену духовної кризи в психології та емпіричним дослідженням особливостей прояву духовної кризи у юнацькому віці. 
Зазначено, що говорити про наявність у людини переживання духовної кризи варто, коли вона усвідомлює, що втратила моральні цінності, а духовність поступилася місцем матеріальній користі.

Зауважено, що духовна криза, яку в технократичній інформаційній ері частково відчуває все людство, є переживанням ситуації неможливості реалізації особистістю власних духовних цінностей у відносинах з іншими людьми і світом, як через їх невідповідність цінностям соціуму чи загальнолюдським, так і через нівелювання їх значущості для самої людини або втрату нею моральних орієнтирів.

У проведеному, відповідно до мети статmі, пілотажному дослідженні вибірку склали студенти Чернівецького національного університету імені Юрія Федьковича - майбутні психологи ( $n=30)$, середній вік досліджуваних - 20 років. Використовувалися методики: "Діагностика духовної кризи», тест життєстійкості С. Мадді, шкала толерантносmі / інтолерантності до невизначеності С. Баднера та шкали «Психологічної розумності» $Х$. Конте.

Виявлено, що схильність до переживання духовної кризи та збільшення напруженості екзистенційного вакууму виявляються студентами з недостатньо розвинутими життєстійкістю та ії компонентами (зокрема, залученістю та прийняттям ризику), яким бракує толерантності у спілкуванні з іншими людьми та психологічної розумності у сприйнятті власного внутрішнього світу, в усвідомленні переживань і відкритості до свого відчуттєвого досвіду.

Зроблено висновок, що ті вчені, які вважають переживання духовної кризи позитивним моментом людського життя, говорять про духовний розвиток і саморозкриття особистості як ії результат, тоді як учені, які сприймають духовну кризу як крах, злам життєвого шляху людини, аналізують ї̈ негативні наслідки і шукають шляхи ії подолання.

Ключові слова: духовна криза, духовність, екзистенційні цінності, сенс життя, духовний розвиток.

\section{Чуйко Галина, Гудима Александр. Духовный кризис личности как признак информационного общества}

\section{АННОТАЦИЯ}

Статья связана с теоретическим анализом интерпретации феномена духовного кризиса в психологии и эмпирическим исследованием особенностей проявления духовного кризиса в юношеском возрасте. 
Отмечено, что говорить о наличии у человека переживания духовного кризиса стоит, когда он осознает, что потерял нравственные ценности, а духовность уступила место материальной корысти.

Подчеркнуто, что духовный кризис, который в технократической информационной эре частично испытывает все человечество, является переживанием ситуации невозможности реализации личностью собственных духовных ценностей в отношениях с другими людьми и миром, как из-за их несоответствия ценностям социума или общечеловеческим, так и из-за нивелирования их значимости для самого человека или потери им нравственных ориентиров.

В проведенном, в соответствии с иелями статьи, пилотажном исследовании выборку составили студенты Черновицкого национального университета имени Юрия Федьковича - будущие психологи $(n=30)$, средний возраст испытуемых - 20 лет. Использовались методики: "Диагностика духовного кризиса», тест жизнестойкости С. Мадди, шкалы толерантности / интолерантности к неопределенности С. Баднера и "Психологической разумности» Х. Конте.

Выявлено, что склонность к переживанию духовного кризиса и увеличению напряженности экзистенциального вакуума проявляется у студентов с недостаточно развитыми жизнестойкостью и ее компонентами (в частности, вовлеченностью и принятием риска); которым не хватает толерантности в общении с другими людьми и психологической разумности в восприятии собственного внутреннего мира, в осознании переживаний и открытости своему чувственному опыту.

Сделан вывод, что те ученые, которые считают переживание духовного кризиса положительным моментом человеческой жизни, говорят о духовном развитии и самораскрытии личности как его резульmame, тогда как ученые, которые воспринимают духовный кризис как крах, слом жизненного пути человека, анализируют его негативные последствия и ищут пути его преодоления.

Ключевые слова: духовный кризис, духовность, экзистенциальные ценности, смысл жизни, духовное развитие. 